\title{
Kinetic studies on the adsorption of phenol from aqueous solution by coffee husk activated carbon
}

\author{
Huu Son Ta ${ }^{1}$, Khu Le Van ${ }^{1, *}$, Thu Thuy Luong Thi ${ }^{1}$ and Thanh Hoa Ha ${ }^{2}$ \\ ${ }^{1}$ Hanoi National University of Education, Faculty of Chemistry, 136 Xuan Thuy, Cau Giay, Hanoi, Vietnam \\ ${ }^{2}$ Electric Power University, Department of Natural Science, 235 Hoang Quoc Viet, Tu Liem, Hanoi, Vietnam
}

\begin{abstract}
The kinetics of phenol adsorption from aqueous solution on activated carbons (ACs) obtained from coffee husk by potassium hydroxide $(\mathrm{KOH})$ activation at 650 and $750^{\circ} \mathrm{C}$ have been studied in the range of $100-250 \mathrm{mg} \mathrm{L}^{-1}$ initial phenol concentrations and at the temperatures range of $10-40^{\circ} \mathrm{C}$. Kinetic models for phenol adsorption were evaluated using pseudo-first-order, pseudo-second-order, and Elovich models. The adsorption mechanism was investigated using Reichenberg, Boyd, and Weber and Morris models. The adsorption on coffee husk activated carbon was found to be a fast or speedy process with the adsorption rate, $\mathrm{k}_{2} \mathrm{q}_{\mathrm{e}}$, in the range of 0.130 to $0.977 \mathrm{~min}^{-1}$. The adsorption process was mainly physical, promoted by chemical sorption, and controlled not only by intra-particle diffusion but also by pore diffusion throughout the entire adsorption period.
\end{abstract}

Keywords: Adsorption; Kinetics; Phenol; Activated carbons; Intra-particle diffusion.

\section{Introduction}

Phenol is a highly toxic pollutant, that is easily found in wastewater from many chemical industries, such as gas, petroleum refinery ${ }^{1}$, resin manufacturing ${ }^{2}$, paper mills ${ }^{3}$, and liquefaction processes ${ }^{4}$. It is difficult to be biodegraded and pose a threat to both human and aquatic environments. Consequently, many countries and international organizations have implemented regulation standards for wastewater discharge.

Several methods and techniques have been extensively used to treat phenolic compounds from wastewater, such as advanced oxidation 5, adsorption ${ }^{6-8}$, extraction ${ }^{9}$, chemical precipitation ${ }^{10}$, membrane separation ${ }^{11}$, and photocatalytic ${ }^{12}$. However, effluent treatment is relatively expensive, especially in large scale applications. With the improvement of the production of activated carbon (AC) from agricultural wastes and reduce the expense ${ }^{13}$, the adsorption method using activated carbon as adsorbent becomes one of the most applicable methods, with the advantages of low cost, simple operation, high effectiveness, and mainly, can remove phenol at low concentration ${ }^{14}$. In this study, the adsorbent is produced from the coffee husk, an abundance precursor in Vietnam, the second-largest exporting coffee country in the world. The adsorption of phenol onto activated carbon is mainly due to the $\pi-\pi$ dispersion interaction between the aromatic ring of phenol with the AC surface in pores

*Corresponding author: Khu Le Van

Email address: khulv@hnue.edu.vn

DOI: http://dx.doi.org/10.13171/mjc10702007271480klv that are similar in size to the phenol molecules, and the interact between the hydroxyl group of the phenol and HO-(AC) or HOOC-(AC) 15,16. These interactions can be described in three sequential processes; namely, i) transport of the adsorbate to the external surface of the adsorbent (film diffusion), ii) transport of the adsorbate within the pores of the adsorbent and small amount of adsorption occur on the external surface (particle diffusion), and iii) physisorption or chemisorption of the adsorbate on the interior surface of the adsorbent ${ }^{17}$.

Nevertheless, the third step is generally considered to be rapid ${ }^{18}$. Therefore, the transfer of the adsorbate in an adsorption process is usually governed by external mass transfer (film diffusion), intra-particle diffusion, or by the combined effect of both diffusion ways ${ }^{19}$. In general, film diffusion is the rate-limiting step that occurs in poor mixing, dilute adsorbate concentration, small particle size, and high affinity of adsorbent. In contrast, systems that have a high adsorbate concentration, proper mixture, large particle size of adsorbent, and low affinity between adsorbent and adsorbate are normally limited by intra-particle diffusion step ${ }^{20}$. Identify the ratelimiting step is a basic requirement to understand the adsorption mechanism and design the actual adsorption and separation process.

This study aims to investigate the kinetics of phenol adsorption onto coffee husk activated carbon. The applicability of kinetic models, namely pseudo-first-

Received May 20, 2020

Accepted June 24, 2020

Published July 27, 2020 
order, pseudo-second-order, and Elovich equations, is evaluated. The activation parameters, such as the activation energy, standard enthalpy, entropy, and free energy of activation, and the adsorption mechanism, are also investigated.

\section{Experimental}

\subsection{Adsorbent and phenol solutions preparation} Arabica coffee husks (from Mai Son, Son La province, Vietnam) were used as a precursor to producing activated carbon, following the same procedure as our previous work ${ }^{21}$. It was washed, dried, and carbonized at $450^{\circ} \mathrm{C}$, in a nitrogen atmosphere for $90 \mathrm{~min}$. The obtained chars were then impregnated with $\mathrm{KOH}$ with a weight ratio of $3 / 1$, for $12 \mathrm{~h}$. The activation process including two steps: i) heated at $400^{\circ} \mathrm{C}$ for 20 minutes and ii) activated at determining temperature $\left(650\right.$ and $\left.750^{\circ} \mathrm{C}\right)$ in $60 \mathrm{~min}$. All the processes were performed at the heating rate of $10^{\circ} \mathrm{C} \mathrm{min}^{-1}$, under a nitrogen flow of $300 \mathrm{~mL} \mathrm{~min}^{-1}$. After activation, the resulted samples were neutralized by $0.1 \mathrm{M} \mathrm{HCl}$ and washed with hot distilled water until neutral $\mathrm{pH}$, then dried at $120^{\circ} \mathrm{C}$ for $24 \mathrm{~h}$ in a vacuum drier. The activated carbons were labeled as ACK-650 and ACK-750, according to the activation temperature. The surface area, pore texture (from BET method ${ }^{22}$ ), and the surface functional groups (from Boehm method ${ }^{23}$ ) of the AC samples are presented in Table 1.

Table 1. Surface area, pore texture, and surface functional groups of activated carbons.

\begin{tabular}{|c|c|c|c|c|c|c|c|c|}
\hline Label & $\begin{array}{c}\text { SBET }_{\text {BET }} \\
\left(\mathbf{m}^{2} \mathbf{g}^{-1}\right)\end{array}$ & $\begin{array}{c}S_{\text {mic }} \\
\left(\mathbf{m}^{2} \mathbf{g}^{-1}\right)\end{array}$ & $\begin{array}{c}\mathbf{S}_{\text {mic }} / \mathbf{S}_{\text {BET }} \\
(\%)\end{array}$ & $\begin{array}{c}V_{\text {mic }} \\
\left(\mathrm{cm}^{3} \mathbf{g}^{-1}\right)\end{array}$ & $\begin{array}{c}V_{\text {mes }} \\
\left(\mathrm{cm}^{3} \mathbf{g}^{-1}\right)\end{array}$ & $\begin{array}{c}\mathbf{V}_{\text {mic }} / \mathbf{V}_{\text {tot }} \\
(\%)\end{array}$ & $\begin{array}{c}\text { Acidic } \\
\text { groups } \\
\left(\mathbf{m m o l} \mathbf{g}^{-1}\right)\end{array}$ & $\begin{array}{c}\text { Basic } \\
\text { groups } \\
\left(\mathbf{m m o l ~ g}^{-1}\right)\end{array}$ \\
\hline ACK-650 & 1216 & 1198 & 98.52 & 0.5281 & 0.0293 & 94.74 & 2.23 & 0.86 \\
\hline ACK-750 & 1905 & 1891 & 99.27 & 0.8252 & 0.0361 & 95.81 & 1.73 & 0.67 \\
\hline
\end{tabular}

Phenol crystals (purity > 99\%, Xylong Chemical, China) were used to prepare adsorbate. A stock solution of $1000 \mathrm{mg} \mathrm{L}^{-1}$ was prepared by weighing the required amount of crystal solid and dissolving in double-distilled water. Different initial concentrations $\left(\mathrm{C}_{\mathrm{o}}\right)$ of phenol, in the range of $100-250 \mathrm{mg} \mathrm{L}^{-1}$, were obtained by dilution of the stock solution without $\mathrm{pH}$ adjustment.

\subsection{Adsorption experiments}

Kinetics experiments were carried out using $250 \mathrm{~mL}$ solution of known initial phenol concentration $\left(100-250 \mathrm{mg} \mathrm{L}^{-1}\right)$ with $0.250 \mathrm{~g}$ of AC (particle size range $0.15<\mathrm{d}<0.3 \mathrm{~mm}$, sieved by No. 100 and No. 50 meshes) in a $300 \mathrm{~mL}$ flask, which was kept in a temperature-controlled water bath $\left(10-40^{\circ} \mathrm{C}\right)$ and the aqueous solution-adsorbent mixtures were stirred at $200 \mathrm{rpm}$. At a preset time intervals, $5 \mathrm{~mL}$ of the mixtures were pipetted out, filtered, and the phenol concentrations were determined according to APHA standard methods ${ }^{24}$. The amount of phenol adsorption at time $\mathrm{t}, \mathrm{q}_{\mathrm{t}}\left(\mathrm{mg} \mathrm{g}^{-1}\right)$, and the phenol adsorption capacity at equilibrium (after $18 \mathrm{~h}$ of stirring), $\mathrm{q}_{\mathrm{e}}\left(\mathrm{mg} \mathrm{g}^{-1}\right)$, were calculated by:

$$
\begin{aligned}
& \mathrm{q}_{\mathrm{t}}=\frac{\left(\mathrm{C}_{\mathrm{o}}-\mathrm{C}_{\mathrm{t}}\right) \mathrm{V}}{\mathrm{m}} \\
& \mathrm{q}_{\mathrm{e}}=\frac{\left(\mathrm{C}_{\mathrm{o}}-\mathrm{C}_{\mathrm{e}}\right) \mathrm{V}}{\mathrm{m}}
\end{aligned}
$$

where $\mathrm{C}_{\mathrm{o}}, \mathrm{C}_{\mathrm{t}}$, and $\mathrm{C}_{\mathrm{e}}\left(\mathrm{mg} \mathrm{\textrm {L } ^ { - 1 }}\right)$ are the phenol concentrations at initial, any time $\mathrm{t}$, and equilibrium, respectively. $\mathrm{V}$ is the volume of the solution (L), and $\mathrm{m}(\mathrm{g})$ is the mass of activated used. In all calculations, the mean values of triplicate experiments of adsorption were used.

\section{Results and Discussion}

3.1. Effect of contact time and initial concentration

The adsorbed amount of phenol on AC prepared from coffee husk was studied as a function of contact time at $30^{\circ} \mathrm{C}$ and different initial phenol concentrations ranging from 100 to $250 \mathrm{mg} \mathrm{L}^{-1}$, the results were presented in Fig. 1. The amount of phenol adsorbed increases rapidly after the first 30 min of contact time, which might be due to the availability of a large number of adsorption sites on the surface of activated carbon. Then, it enhanced slowly as a result of surface saturation, and finally headed toward equilibrium. The amount of phenol uptake is reinforced at the increasing of initial phenol concentration from 100 to $250 \mathrm{mg} \mathrm{L}^{-1}$, regardless of contact time and adsorbents, owing to the stronger thermodynamic driving force at a high concentration gradient ${ }^{25}$. In all cases, the amount of phenol adsorbed on ACK-750 sample are always higher than that on ACK-650 sample under identical conditions, owing to the large specific surface area and pore volume of ACK-750 sample. 

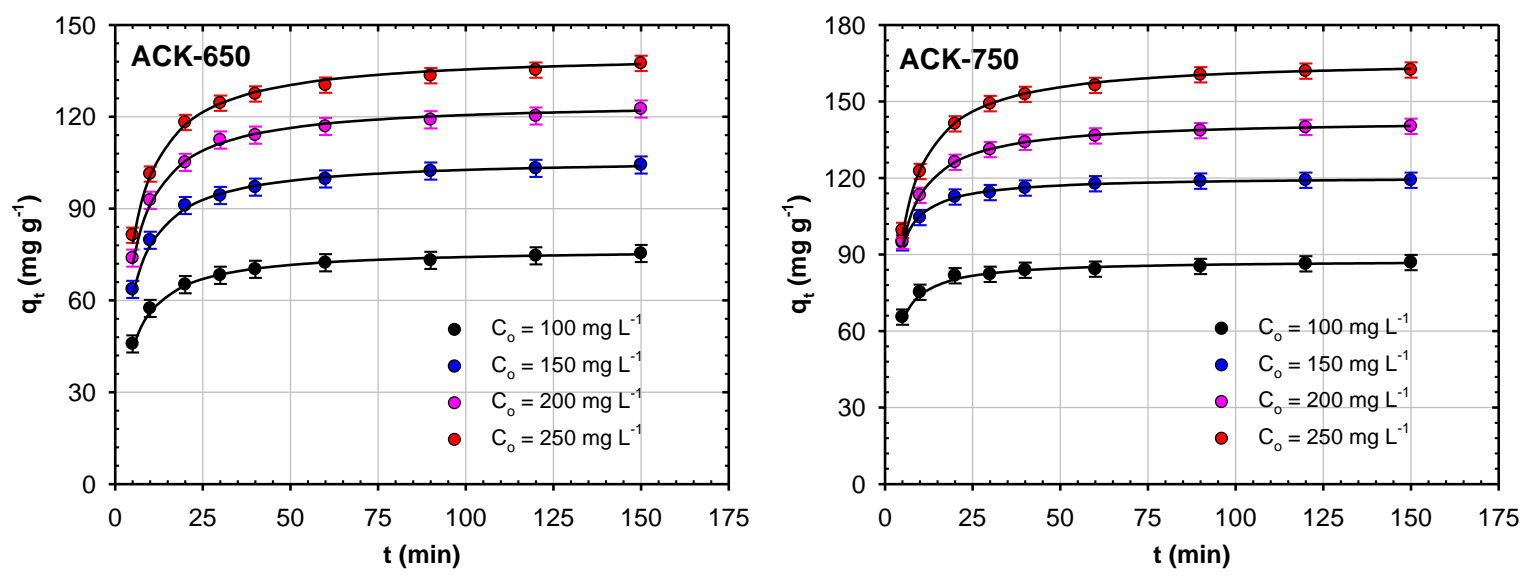

Figure 1. Adsorption kinetics of phenol at $30^{\circ} \mathrm{C}$ on the activated carbon (The solid curves were calculated by the PSO equation)

\subsection{Adsorption kinetic study}

To interpret the correlations between the amount of phenol adsorbed and time, three kinetic models, that is, the pseudo-first-order (PFO), pseudo-secondorder (PSO), and Elovich equations were applied.

The PFO equation of Lagergren ${ }^{26}$ is given as:

$\ln \left(\mathrm{q}_{\mathrm{e}}-\mathrm{q}_{\mathrm{t}}\right)=\ln \mathrm{q}_{\mathrm{e}}-\mathrm{k}_{1} \mathrm{t}$

The PSO ${ }^{27}$ equation is given as:

$\frac{\mathrm{t}}{\mathrm{q}_{\mathrm{t}}}=\frac{1}{\mathrm{k}_{2} \mathrm{q}_{\mathrm{e}}^{2}}+\frac{1}{\mathrm{q}_{\mathrm{e}}} \mathrm{t}$

The Elovich equation is general expressed as follow ${ }^{28}$ :

$\mathrm{q}_{\mathrm{t}}=(1 / \beta) \ln (\alpha \beta)+(1 / \beta) \ln (\mathrm{t})$

where $\mathrm{k}_{1}$ is the PFO rate constant $\left(\mathrm{min}^{-1}\right), \mathrm{k}_{2}$ is the PSO constant $\left(\mathrm{g} \mathrm{mg}^{-1} \mathrm{~min}^{-1}\right), \alpha$ is initial adsorption rate $\left(\mathrm{mg} \mathrm{g}^{-1} \mathrm{~min}^{-1}\right)$, and $\beta$ is desorption constant $\left(\mathrm{g} \mathrm{mg}^{-1}\right)$.

The parameters of the PFO, PSO, and the Elovich models were obtained using linear regression. The applicability of these equations is verified through the coefficient of determination $\left(\mathrm{R}^{2}\right)$ and the average relative errors (ARE) ${ }^{29}$, in which $\mathrm{R}^{2}$ is used to evaluate the correlation between experimental data and kinetic equation, and the ARE are used to estimate the fit between the experimental and predicted data. ARE are calculated according to equation (6):

$\operatorname{ARE}=\frac{100}{\mathrm{~N}} \sum_{\mathrm{i}=1}^{\mathrm{N}}\left|\left(\frac{\mathrm{q}_{\mathrm{t}, \mathrm{pre}}-\mathrm{q}_{\mathrm{t}, \mathrm{mes}}}{\mathrm{q}_{\mathrm{t}, \mathrm{mes}}}\right)_{\mathrm{i}}\right|$

where $\mathrm{q}_{\mathrm{t}, \mathrm{mes}}$, and $\mathrm{q}_{\mathrm{t}, \text { pre }}$ are experimental and predicted, amount of phenol adsorbed at time $\mathrm{t}$ respectively; $\mathrm{N}$ is the number of experimental data.

The PFO, PSO, and Elovich kinetic models have been determined at different initial phenol concentrations and showed in Fig. 2 and Fig. 3. It can be seen that at all contact time and initial concentration investigated, the experimental points scattered around PFO and Elovich lines, whereas lie precisely on the PSO line. The obtained kinetic parameters, along with the corresponding $\mathrm{R}^{2}$ and ARE values of the three models, are summarized in Table 2. As can be seen from Table 2:

i) For the PFO model, the values of the coefficient of determination $\mathrm{R}^{2}$ are in the range of $0.8454-0.9342$ and ARE values are very high for both samples (85.27 - 86.00 for ACK-650 sample and 87.02 91.66 for ACK-750 sample), proving a poor fit of the model. Furthermore, the calculated $\mathrm{q}_{\mathrm{e}}$ and the experimental $\mathrm{q}_{\mathrm{e}}$ differ appreciably. Therefore, the adsorption of phenol onto coffee husk AC cannot be described by the PFO model.

ii) The Elovich model shows a coefficient of determination $\mathrm{R}^{2}$ in the range of $0.8539-0.9120$, and a relative large ARE values $(3.78-4.05$ for ACK-650 and 2.12 - 3.77 for ACK-750). Therefore, in this study, the Elovich model is inappropriate to describe the kinetic adsorption of phenol onto ACs.

iii) The PSO model obviously yielded the highest $R^{2}$ $(0.9998-0.9999)$ and the smallest ARE values $(0.28-0.96) . R^{2}$ close to 1, ARE is very small, and the experimental value $\mathrm{q}_{\mathrm{e}}$ agrees with the calculated one, inferring that the kinetic of phenol adsorption of phenol onto coffee husk AC can be described very well by PSO model. Other published studies in the literature have also been reported that the PSO model is applicable in the case of phenol adsorption on $\mathrm{ACs}^{30}$. 

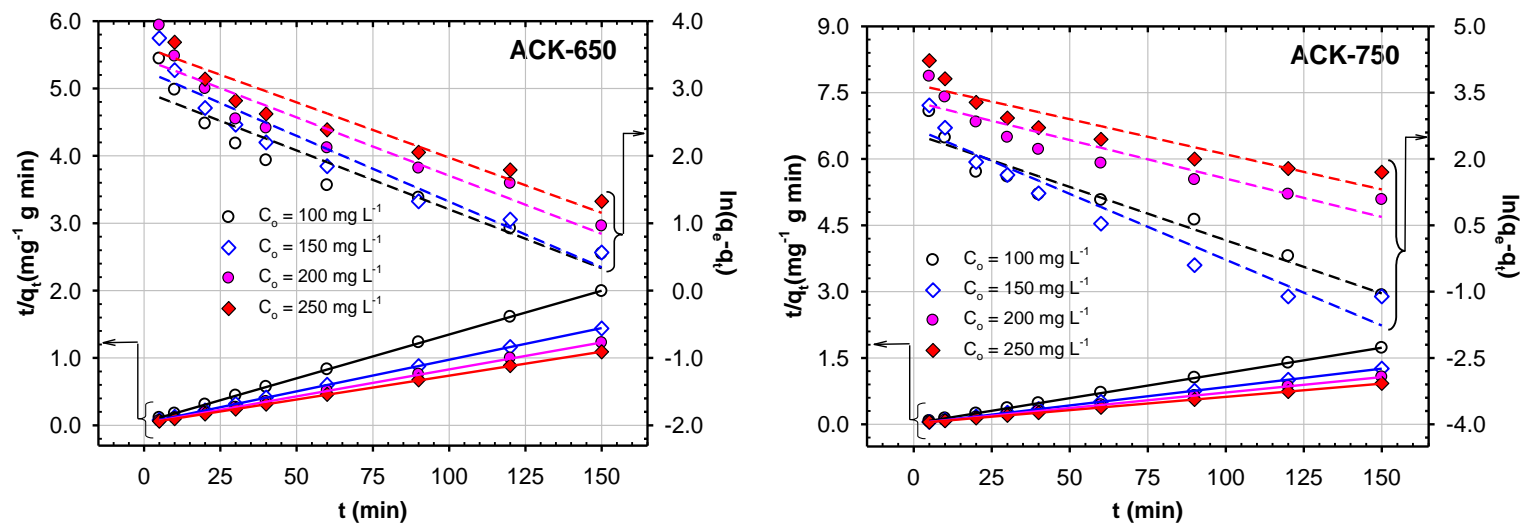

Figure 2. PFO and PSO kinetics models for phenol adsorption at $30^{\circ} \mathrm{C}$ on the coffee husk AC (The solid and dash curves were calculated by the PSO and PFO equation, respectively)
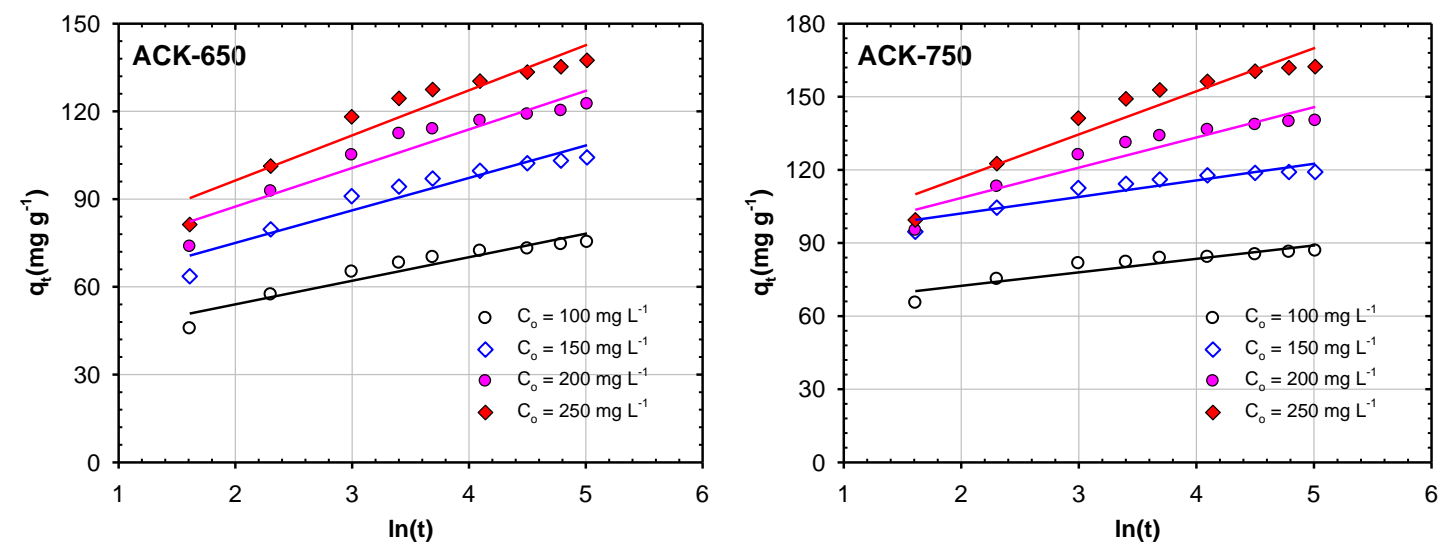

Figure 3. Elovich kinetic model for phenol adsorption at $30^{\circ} \mathrm{C}$ on the coffee husk $\mathrm{AC}$

Table 2. Kinetic parameters for the adsorption of phenol at $30^{\circ} \mathrm{C}$ on the coffee husk AC.

\begin{tabular}{|c|c|c|c|c|c|c|c|c|c|}
\hline \multirow{2}{*}{\multicolumn{2}{|c|}{$\begin{array}{c}\text { Sample } \\
\mathrm{C}_{\mathrm{o}}\left(\mathrm{mg} \mathrm{L}^{-1}\right)\end{array}$}} & \multicolumn{4}{|c|}{ ACK-650 } & \multicolumn{4}{|c|}{ ACK-750 } \\
\hline & & 100 & 150 & 200 & 250 & 100 & 150 & 200 & 250 \\
\hline \multicolumn{2}{|c|}{ Experimental $\mathrm{q}_{\mathrm{e}}\left(\mathrm{mg} \mathrm{g}^{-1}\right)$} & 77.08 & 106.02 & 125.16 & 141.22 & 87.18 & 119.45 & 143.19 & 167.82 \\
\hline \multirow{4}{*}{$\begin{array}{l}\text { Pseudo- } \\
\text { first-order }\end{array}$} & $\mathrm{q}_{\mathrm{e}}\left(\mathrm{mg} \mathrm{g}^{-1}\right)$ & 19.20 & 26.32 & 31.05 & 37.07 & 13.08 & 14.88 & 27.02 & 40.21 \\
\hline & $\mathrm{k}_{1} \times 10^{2}\left(\mathrm{~min}^{-1}\right)$ & 1.75 & 1.95 & 1.73 & 1.64 & 2.41 & 2.98 & 1.74 & 1.59 \\
\hline & $\mathrm{R}^{2}$ & 0.8987 & 0.9199 & 0.8867 & 0.8877 & 0.9342 & 0.9268 & 0.8556 & 0.8454 \\
\hline & $\operatorname{ARE}(\%)$ & 85.87 & 85.27 & 86.00 & 85.45 & 90.62 & 91.66 & 89.56 & 87.02 \\
\hline \multirow{6}{*}{$\begin{array}{l}\text { Pseudo- } \\
\text { second- } \\
\text { order }\end{array}$} & $\mathrm{q}_{\mathrm{e}}\left(\mathrm{mg} \mathrm{g}^{-1}\right)$ & 76.92 & 106.38 & 125.00 & 140.85 & 87.72 & 120.48 & 142.86 & 166.67 \\
\hline & $\begin{array}{c}\mathrm{k}_{2} \times 10^{3} \\
\left(\mathrm{~g} \mathrm{mg}^{-1} \min ^{-1}\right)\end{array}$ & 3.52 & 2.58 & 2.18 & 1.79 & 6.19 & 5.74 & 2.68 & 1.71 \\
\hline & $\mathrm{k}_{2} \mathrm{q}_{\mathrm{e}}\left(\min ^{-1}\right)$ & 0.271 & 0.275 & 0.272 & 0.252 & 0.543 & 0.692 & 0.383 & 0.284 \\
\hline & $\mathrm{h}\left(\mathrm{mg} \mathrm{g}^{-1} \mathrm{~min}^{-1}\right)$ & 20.8 & 29.2 & 34.0 & 35.5 & 47.6 & 83.3 & 54.6 & 47.4 \\
\hline & $\mathrm{R}^{2}$ & 0.9999 & 0.9999 & 0.9998 & 0.9999 & 0.9999 & 0.9999 & 0.9999 & 0.9999 \\
\hline & $\operatorname{ARE}(\%)$ & 0.92 & 0.96 & 0.96 & 0.95 & 0.87 & 0.38 & 0.28 & 0.44 \\
\hline \multirow{4}{*}{ Elovich } & $\alpha\left(\mathrm{mg} \mathrm{g}^{-1} \mathrm{~min}^{-1}\right)$ & 887 & 1294 & 1353 & 1079 & 367271 & 3097748 & 10514 & 1775 \\
\hline & $\beta\left(\mathrm{g} \mathrm{mg}^{-1}\right)$ & 0.124 & 0.090 & 0.076 & 0.065 & 0.181 & 0.147 & 0.081 & 0.057 \\
\hline & $\mathrm{R}^{2}$ & 0.9111 & 0.9103 & 0.9031 & 0.9120 & 0.8539 & 0.8769 & 0.8924 & 0.9078 \\
\hline & $\operatorname{ARE}(\%)$ & 3.92 & 3.78 & 4.05 & 3.93 & 2.67 & 2.12 & 3.31 & 3.77 \\
\hline
\end{tabular}

For the PSO model, with increasing initial phenol concentration, the rate constant $\mathrm{k}_{2}$ gradually decreased, faster for ACK-750 sample (from $6.19 \times 10^{-3}$ to $1.71 \times 10^{-3} \mathrm{~g} \mathrm{mg}^{-1} \mathrm{~min}^{-1}$ ), and slower 
for ACK-650 sample (from $3.52 \times 10^{-3}$ to $\left.1.79 \times 10^{-3} \mathrm{~g} \mathrm{mg}^{-1} \mathrm{~min}^{-1}\right)$. At the highest concentration investigated, $\mathrm{k}_{2}$ declined to a similar value for both examples. From the PSO kinetic

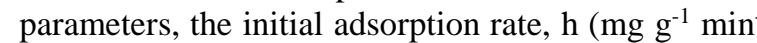
$\left.{ }^{1}\right)$, at different initial phenol concentrations was calculated using equation (7) ${ }^{31}$ and given in Table 2.

$\mathrm{h}=\mathrm{k}_{2} \mathrm{q}_{\mathrm{e}}^{2}$

The initial adsorption rate changes differently according to the shift of $\mathrm{C}_{\mathrm{o}}$. For the ACK-650 sample, $\mathrm{h}$ gradually increases from 20.8 to $35.5 \mathrm{mg} \mathrm{g}^{-1} \mathrm{~min}^{-1}$ when $\mathrm{C}_{\mathrm{o}}$ is rising from 100 to $250 \mathrm{mg} \mathrm{g}^{-1}$. Whereas for ACK-750 sample, $\mathrm{h}$ raises from 47.6 to $83.3 \mathrm{mg} \mathrm{g}^{-1} \mathrm{~min}^{-1}$ when $\mathrm{C}_{\mathrm{o}}$ increasing from 100 to $150 \mathrm{mg} \mathrm{L}^{-1}$, then decreases back to $47.4 \mathrm{mg} \mathrm{g}^{-1} \mathrm{~min}^{-1}$ when Co reaches $250 \mathrm{mg}$ $\mathrm{L}^{-1}$. The difference in the behavior variation of the initial adsorption rate between ACK-650 and ACK-750 samples might be explained by the number

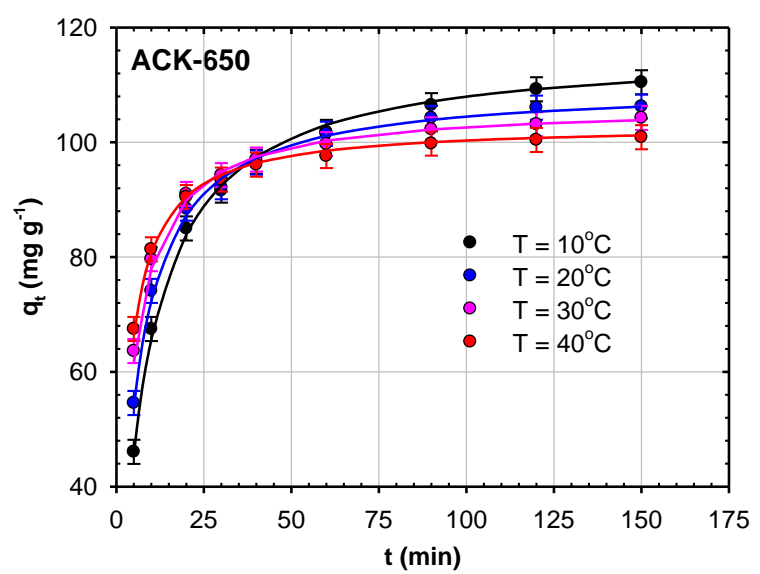

of micropores of two samples. The high amount of micropore $\left(1891 \mathrm{~m}^{2} \mathrm{~g}^{-1}\right)$ of the ACK-750 sample might hinder the mass transfer of phenol diffusion inside micropores at concentrations higher than $150 \mathrm{mg} \mathrm{L}^{-1}$.

\subsection{Effect of temperature}

The effect of temperature on the adsorption of phenol from aqueous solution on coffee husk $\mathrm{AC}$ is examined with the initial phenol concentration of $150 \mathrm{mg} \mathrm{L}^{-1}$, in temperatures range of $10-40^{\circ} \mathrm{C}$ and presented in Fig. 4. At the initial stage of contact time, the amount of phenol uptake increases with temperature. However, after longer contact time, 50 min for ACK-650, and 35 min for ACK-750, the amount of phenol adsorbed decreased at increasing temperature, which might be due to the desorption of phenol adsorbed from activated carbon and progress toward equilibrium. It also can be seen the phenol uptake of ACK-750 sample are always higher than that of ACK-650 sample at all temperature studied.

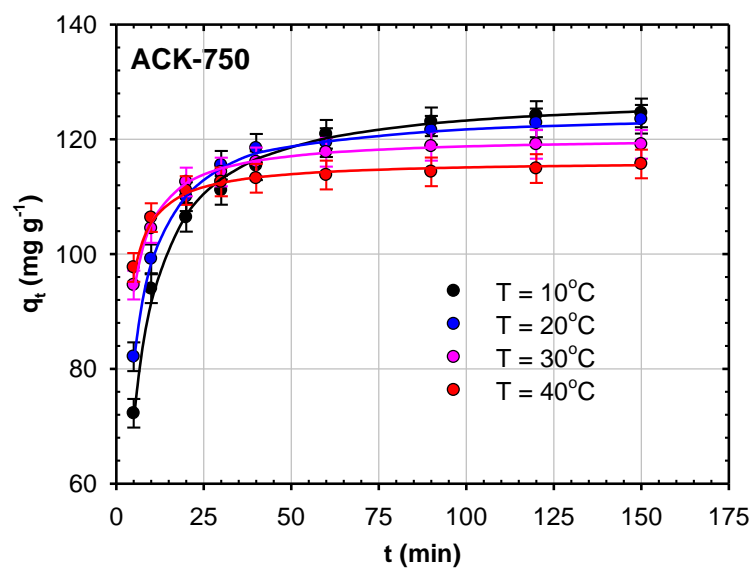

Figure 4. Adsorption kinetics of phenol on the activated carbon at initial phenol concentration of $150 \mathrm{mg} \mathrm{L}^{-1}$ and different temperatures (The solid curves were calculated by the PSO equation)

Table 3. Calculated parameters of the PSO in the phenol adsorption at initial phenol concentration of $150 \mathrm{mg} \mathrm{L}^{-1}$ and different temperatures on the coffee husk AC.

\begin{tabular}{|c|c|c|c|c|c|c|c|c|}
\hline Sample & $\begin{array}{c}\mathbf{T} \\
\left({ }^{\circ} \mathbf{C}\right)\end{array}$ & $\begin{array}{c}\text { Experimental } \\
\text { qe }\left(\mathrm{mg} \mathrm{g}^{-1}\right)\end{array}$ & $\begin{array}{c}q \mathrm{e} \\
\left(\mathrm{mg} \mathrm{g^{-1 }}\right)\end{array}$ & $\begin{array}{c}\mathrm{k}_{2} \times 10^{3} \\
\left(\mathrm{~g} \mathrm{mg}^{-1} \mathrm{~min}^{-1}\right)\end{array}$ & $\begin{array}{c}\mathbf{k}_{2 q} \\
\left(\mathrm{~min}^{-1}\right)\end{array}$ & $\underset{\left(\mathrm{mg} \mathrm{g}^{-1} \min ^{-1}\right)}{h}$ & $\mathbf{R}^{2}$ & $\begin{array}{c}\text { ARE } \\
(\%)\end{array}$ \\
\hline \multirow{4}{*}{ ACK-650 } & 10 & 116.30 & 116.28 & 1.12 & 0.130 & 15.1 & 0.9999 & 0.94 \\
\hline & 20 & 109.41 & 109.89 & 1.75 & 0.193 & 21.2 & 0.9999 & 0.97 \\
\hline & 30 & 106.02 & 106.38 & 2.58 & 0.275 & 29.2 & 0.9999 & 0.96 \\
\hline & 40 & 103.22 & 103.09 & 3.50 & 0.361 & 37.2 & 0.9999 & 0.63 \\
\hline \multirow{4}{*}{ ACK-750 } & 10 & 127.66 & 128.21 & 1.95 & 0.250 & 32.1 & 0.9999 & 0.92 \\
\hline & 20 & 125.54 & 125.00 & 2.96 & 0.370 & 46.3 & 0.9999 & 0.58 \\
\hline & 30 & 119.45 & 120.48 & 5.74 & 0.692 & 83.3 & 0.9999 & 0.38 \\
\hline & 40 & 116.48 & 116.28 & 8.40 & 0.977 & 113.6 & 0.9999 & 0.47 \\
\hline
\end{tabular}

The calculated parameters at different temperatures, according to the PSO model, are summarized in Table 3. It can be seen that $\mathrm{R}^{2}$ in all cases is close to 1, ARE values are less than 1 . All the calculated $\mathrm{q}_{\mathrm{e}}$ are in the same range as the experimental $\mathrm{q}_{\mathrm{e}}$, inferring that the PSO model can be successfully described the adsorption of phenol onto coffee husk $\mathrm{AC}$ at different temperatures. It also can be seen that the $\mathrm{h}$ and $\mathrm{k}_{2}$ values increase with a rise in temperature. This may be explained by an increase in 
the interaction between phenol and activated carbon, due to faster transport from the bulk solution to activated carbon surfaces, as well as the faster pores diffusion at rising temperatures. Furthermore, for both AC samples, $\mathrm{q}_{\mathrm{e}}$ decreases as increasing adsorption temperature, suggesting the exothermic nature of the adsorption process.

From the PSO kinetic parameters, the adsorption rate of approaching equilibrium can be determined by $\mathrm{k}_{2} \mathrm{q}_{\mathrm{e}}$, and classified to slow process if $\mathrm{k}_{2} \mathrm{q}_{\mathrm{e}},<0.01$, moderately fast process if $0.01<\mathrm{k}_{2} \mathrm{q}_{\mathrm{e}}<0.1 \mathrm{~min}^{-1}$, fast process if $0.1<\mathrm{k}_{2} \mathrm{q}_{\mathrm{e}}<0.8 \mathrm{~min}^{-1}$, and extremely fast process if $\mathrm{k}_{2} \mathrm{q}_{\mathrm{e}}>0.8 \min ^{-1}{ }^{32}$. The values of $\mathrm{k}_{2} \mathrm{q}_{\mathrm{e}}$ at different initial phenol concentrations and temperatures for the phenol adsorption on coffee husk AC are calculated and reported in Table 1 and Table $2 . \mathrm{k}_{2} \mathrm{q}_{\mathrm{e}}$ is increasing from 0.130 to $0.361 \mathrm{~min}^{-1}$ for ACK-650 sample, and from 0.250 to $0.977 \mathrm{~min}^{-1}$ for ACK-750 sample when temperature increase from 10 to $40^{\circ} \mathrm{C}$ (Table 2). $\mathrm{k}_{2} \mathrm{q}_{\mathrm{e}}$ also lies in the range of 0.252 to $0.692 \mathrm{~min}^{-1}$ for both samples when initial phenol concentration in the range of 100 to $250 \mathrm{mg} \mathrm{L}^{-1}$ (Table 1). This result shows that phenol adsorption onto ACK-650 is a fast process in the temperature range of $10-40^{\circ} \mathrm{C}$, whereas $\mathrm{ACK}-750$ is a fast process in the temperature range of $10-30^{\circ} \mathrm{C}$ and is a speedy process at $40^{\circ} \mathrm{C}$. This is an advantage of coffee husk AC in practical application, compared to other types of AC. The process of phenol adsorption onto coffee husk $\mathrm{AC}$ is tremendously faster than onto coconut shells $\mathrm{AC}$ $\left(\mathrm{k}_{2} \mathrm{q}_{\mathrm{e}}=0.0169 \mathrm{~min}^{-1}\right)^{33}$, plum kernel $\mathrm{AC} 750^{\circ} \mathrm{C}$ $\left(\mathrm{k}_{2} \mathrm{q}_{\mathrm{e}}=0.0169 \mathrm{~min}^{-1}\right)^{34}$, or granular $\mathrm{AC}$ $\left(\mathrm{k}_{2} \mathrm{q}_{\mathrm{e}}=0.0108 \mathrm{~min}^{-1}\right)^{35}$.

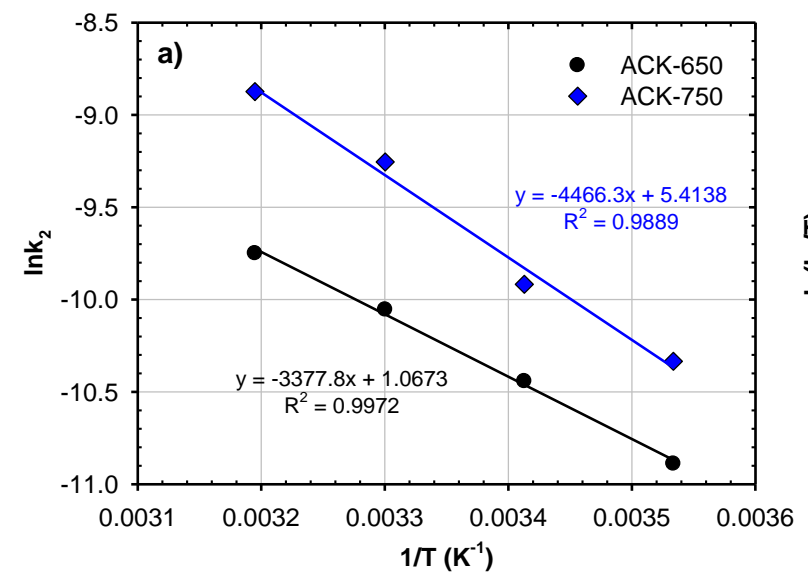

\subsection{Activation parameters}

The activation energy $E_{a}$ for phenol adsorption onto coffee husk AC was determined using the Arrhenius equation:

$$
\ln \mathrm{k}_{2}=\ln \mathrm{A}-\frac{\mathrm{E}_{\mathrm{a}}}{\mathrm{RT}}
$$

where $\mathrm{k}_{2}$ is the PSO rate constant $\left(\mathrm{g} \mathrm{g}^{-1} \mathrm{~s}^{-1}\right), \mathrm{E}_{\mathrm{a}}$ is the activation energy $\left(\mathrm{kJ} \mathrm{mol}^{-1}\right), \mathrm{A}$ is the Arrhenius factor, $\mathrm{R}$ is the gas constant $\left(8.314 \mathrm{~J} \mathrm{~mol}^{-1} \mathrm{~K}^{-1}\right)$, and $\mathrm{T}$ is the absolute temperature $(\mathrm{K})$.

The dependence of $\operatorname{lnk}_{2}$ on the reciprocal temperature is showed in Fig. 5a. $\mathrm{E}_{\mathrm{a}}$ was obtained from the slope of the linear plot. The value of $E_{a}$ (Table 3) was $28.083 \mathrm{~kJ} \mathrm{~mol}^{-1}$ for the ACK-650 sample and is $37.133 \mathrm{~kJ} \mathrm{~mol}^{-1}$ for the ACK-750 sample. These calculated activation energies for both samples are less than $40 \mathrm{~kJ} \mathrm{~mol}^{-1}$ demonstrating a quick reaction ${ }^{36}$, which is in agreement with the result obtained from $\mathrm{k}_{2} \mathrm{q}_{\mathrm{e}}$ values. These results are comparable to the adsorption of sulfonated methyl phenol resin on sewage sludge-derived adsorbent ${ }^{37}$. On the other hand, the magnitude of $E_{a}$ may give an idea about the type of adsorption. According to literature ${ }^{38}$, if $\mathrm{E}_{\mathrm{a}}$ value is between 5 and $20 \mathrm{~kJ} \mathrm{~mol}^{-1}$ physisorption is the predominant process, and if $\mathrm{E}_{\mathrm{a}}>40 \mathrm{~kJ} \mathrm{~mol}^{-1}$, the chemical reaction process will take place. Therefore, the adsorption of phenol from aqueous solution onto coffee husk AC in this study is mainly physical and boosted by chemisorption. The chemisorption is due to the surface functional groups of AC samples, especially basic groups, which can form donor-acceptor complexes with phenol, thus contributing to phenol adsorption ${ }^{6}$.

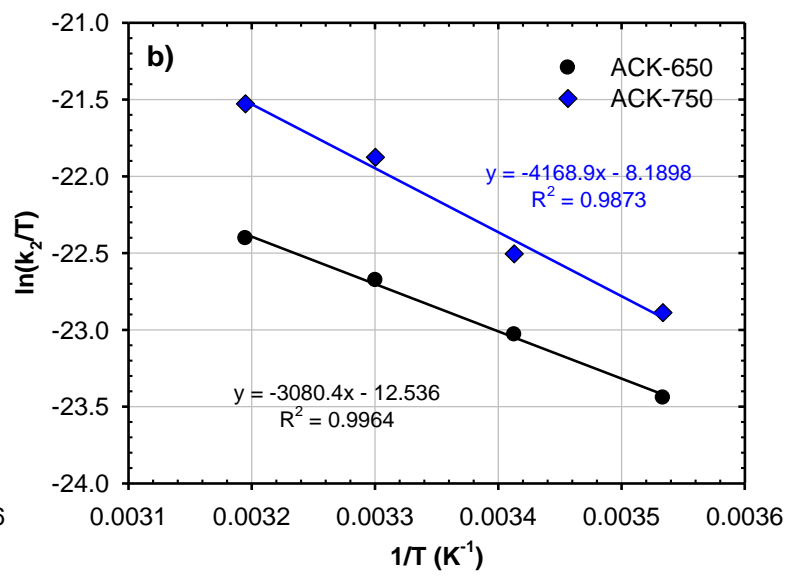

Figure 5. Plot of $\ln _{2}$ vs $1 / \mathrm{T}$ (a) and $\ln \left(\mathrm{k}_{2} / \mathrm{T}\right)$ vs $1 / \mathrm{T}$ (b)

The Eyring equation was used to calculate the standard enthalpy $\left(\Delta \mathrm{H}^{\#}\right)$, entropy $\left(\Delta \mathrm{S}^{\#}\right)$, and free energy $\left(\Delta G^{\#}\right)$ of activation as followed:

$\ln \frac{\mathrm{k}_{2}}{\mathrm{~T}}=\ln \frac{\mathrm{k}_{\mathrm{b}}}{\mathrm{h}}+\frac{\Delta \mathrm{S}^{\#}}{\mathrm{R}}-\frac{\Delta \mathrm{H}^{\#}}{\mathrm{RT}}$

$\Delta \mathrm{G}^{\#}=\Delta \mathrm{H}^{\#}-\mathrm{T} \Delta \mathrm{S}^{\#}$ where $\mathrm{k}_{2}$ is the PSO rate constant $\left(\mathrm{g} \mathrm{g}^{-1} \mathrm{~s}^{-1}\right), \mathrm{k}_{\mathrm{b}}$ and $\mathrm{h}$ are the Boltzmann's constant $\left(1.381 \times 10^{-23} \mathrm{~J} \mathrm{~K}^{-1}\right)$ and Planck's constant $\left(6.626 \times 10^{-34} \mathrm{~J} \mathrm{~s}\right)$, respectively. $\Delta \mathrm{H}^{\#}$ and $\Delta \mathrm{S}^{\#}$ were calculated from the slope and intercept of the plot of $\ln \left(\mathrm{k}_{2} / \mathrm{T}\right)$ versus $1 / \mathrm{T}$ (Fig. $5 \mathrm{~b}$ ), and the acquired activation parameters are reported in Table 4. 
Table 4. Activation parameters for the adsorption of phenol onto coffee husk AC.

\begin{tabular}{|c|c|c|c|c|c|}
\hline Samples & $\begin{array}{c}\mathbf{T} \\
\left({ }^{\circ} \mathbf{C}\right)\end{array}$ & $\begin{array}{c}\Delta \mathbf{G}^{\#} \\
\left(\mathrm{~kJ} \mathrm{~mol}^{-1}\right)\end{array}$ & $\begin{array}{c}\Delta \mathbf{H}^{\#} \\
\left(\mathrm{~kJ} \mathrm{~mol}^{-1}\right)\end{array}$ & $\begin{array}{c}\Delta \mathbf{S}^{\#} \\
\left(\mathbf{J ~ m o l}^{-1} \mathbf{K}^{-1}\right)\end{array}$ & $\begin{array}{c}\mathbf{E}_{\mathrm{a}} \\
\left(\mathrm{kJ} \mathrm{mol}^{-1}\right)\end{array}$ \\
\hline \multirow{4}{*}{ ACK-650 } & 10 & 111.010 & \multirow{4}{*}{25.610} & \multirow{4}{*}{-301.8} & \multirow{4}{*}{28.083} \\
\hline & 20 & 114.028 & & & \\
\hline & 30 & 117.046 & & & \\
\hline & 40 & 120.064 & & & \\
\hline \multirow{4}{*}{$\mathrm{ACK}-750$} & 10 & 109.834 & \multirow{4}{*}{34.660} & \multirow{4}{*}{-265.6} & \multirow{4}{*}{37.133} \\
\hline & 20 & 112.491 & & & \\
\hline & 30 & 115.147 & & & \\
\hline & 40 & 117.803 & & & \\
\hline
\end{tabular}

In the temperature range of $10-40^{\circ} \mathrm{C}, \Delta \mathrm{G}^{\#}$ ranging from 111.010 to $120.064 \mathrm{~kJ} \mathrm{~mol}^{-1}$ for ACK-650 sample and from 109.834 to $117.803 \mathrm{~kJ} \mathrm{~mol}^{-1}$ for ACK-750 sample, suggests that in the activation step, the adsorption reaction requires energy to convert reactants into products. The positive value of $\Delta \mathrm{H}^{\#}\left(25.610 \mathrm{~kJ} \mathrm{~mol}^{-1}\right.$ for ACK-650 sample, and $34.660 \mathrm{~kJ} \mathrm{~mol}^{-1}$ for ACK-750 sample) indicates endothermic nature, meaning the reaction consumes energy. The negative value of $\Delta S^{\#} \quad(-301.8$ and $-265.6 \mathrm{~J} \mathrm{~mol}{ }^{-1} \mathrm{~K}^{-1}$ for ACK-650 and ACK-750 samples) suggests that the adsorption of phenol decrease randomly of the surface, inferring that the adsorption of phenol onto coffee husk AC surface is an associated mechanism ${ }^{39}$. Also, the negative value of $\Delta S^{\#}$ usually reflects that no significant change occurs in the internal structure of the adsorbent during the adsorption process ${ }^{40}$.

\subsection{Adsorption mechanism study}

In order to estimate the rate-determining step in the adsorption process of phenol onto activated carbon and explain the adsorption mechanism, the data were further investigated using Reichenberg (film

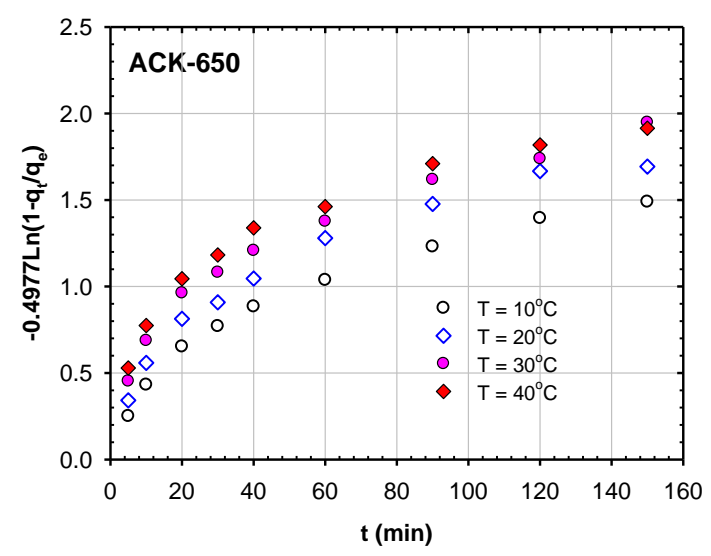

diffusion), Boyd (particle diffusion), and Weber and Morris (intra-particle diffusion) models.

\subsubsection{Reichenberg model}

The Reichenberg model ${ }^{41}$ is usually applicable to film diffusion inside micropores and is expressed in the following equation:

$\mathrm{f}\left(\frac{\mathrm{q}_{\mathrm{t}}}{\mathrm{q}_{\mathrm{e}}}\right)=\left(1-\frac{6}{\pi^{2}}\right) \exp (-\mathrm{Bt})$

Or simplified as in the linear form:

$$
-0.4977 \ln \left(1-\frac{\mathrm{q}_{\mathrm{t}}}{\mathrm{q}_{\mathrm{e}}}\right)=\mathrm{Bt}
$$

where $\mathrm{q}_{\mathrm{t}}$ and $\mathrm{q}_{\mathrm{e}}$ are the amount of phenol adsorbed at time $t$ and equilibrium, $B$ is the time constant.

The plots of $-0.4977 \ln \left(1-q_{t} / q_{e}\right)$ versus $t$ for ACK-650 and ACK-750 samples, at different temperatures, showed in Fig. 6 do not follow linear relation, suggesting that film diffusion is not the sole ratecontrolling process.

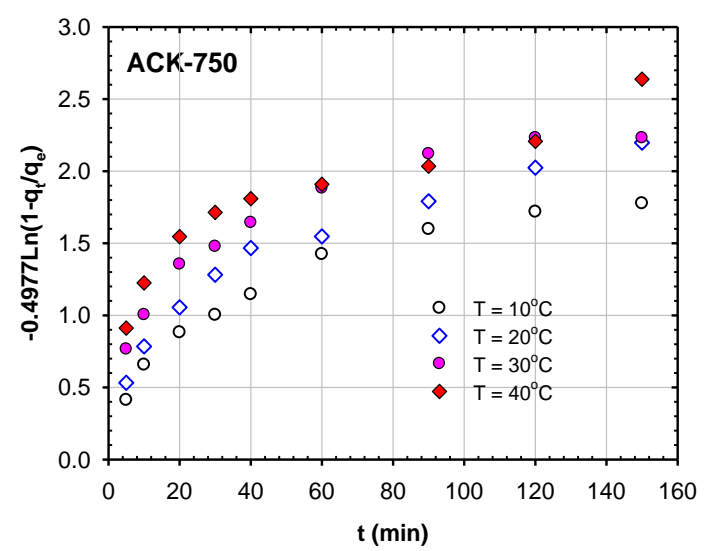

Figure 6. Reichenberg model plot for phenol adsorption on the activated carbon at different temperatures

\subsubsection{Boyd model}

The Boyd model ${ }^{42}$ represented a particle diffusion model, signifying for diffusion rate during adsorption, as shown in the following equation:

$$
\mathrm{f}\left(\frac{\mathrm{q}_{\mathrm{t}}}{\mathrm{q}_{\mathrm{e}}}\right)=1-\frac{6}{\pi^{2}} \sum_{\mathrm{n}_{1}=1}^{\alpha} \frac{1}{\mathrm{n}_{1}^{2}} \exp \left(-\frac{\mathrm{D}_{\mathrm{e}} \mathrm{t} \pi^{2} \mathrm{n}_{1}^{2}}{\mathrm{R}_{\mathrm{a}}^{2}}\right)
$$

Assuming the adsorbent as spherical, the Vermeulen approximates it as in equation: 
$-\ln \left[1-\left(\frac{\mathrm{q}_{\mathrm{t}}}{\mathrm{q}_{\mathrm{e}}}\right)^{2}\right]=\frac{\pi^{2}}{\mathrm{R}_{\mathrm{a}}^{2}} \mathrm{D}_{\mathrm{e}} \mathrm{t}$

where $R_{a}$ is the radius of adsorbent, and $D_{e}$ is the effective diffusion coefficient.

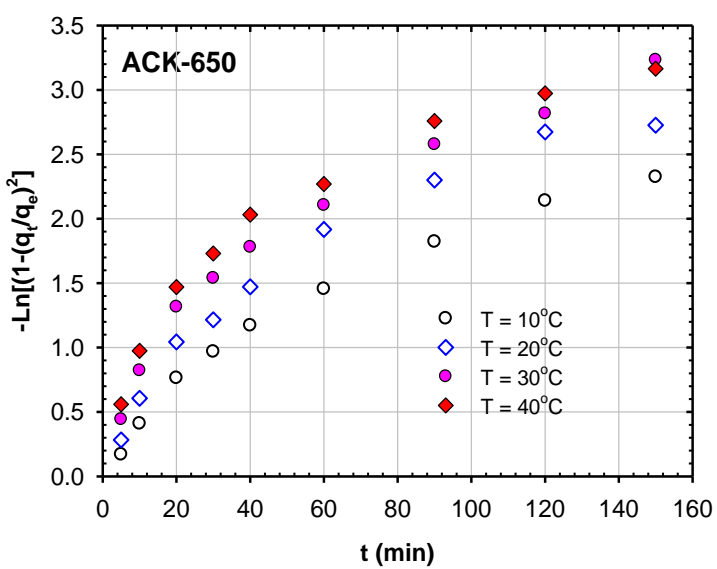

Figure 7. Boyd model plot for phenol adsorption on the activated carbon at different temperatures

The experimental data did not give a good correlation since the plots of $-\ln \left[1-\left(\mathrm{q}_{\mathrm{t}} / \mathrm{q}_{\mathrm{e}}\right)^{2}\right]$ versus $\mathrm{t}$ at all temperatures followed a non-linear relationship. This
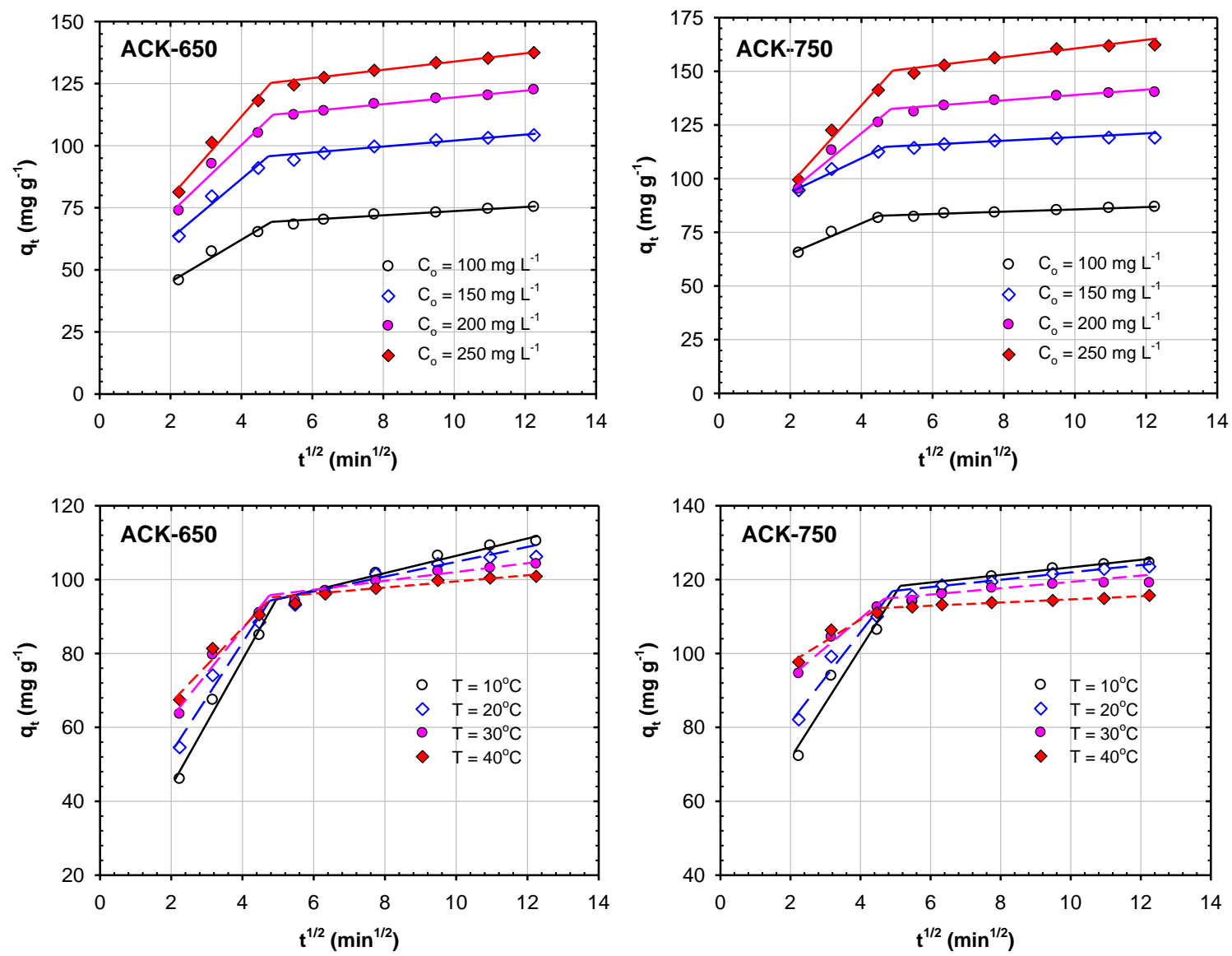

Figure 8. Intra-particle diffusion model plot for phenol adsorption on the activated carbon

\subsubsection{Weber and Morris model}

The intra-particle diffusion model was used to study the mechanisms involved and to identify the ratecontrolling step. This model described by Weber and Morriss ${ }^{43}$ is shown in Eq (15).

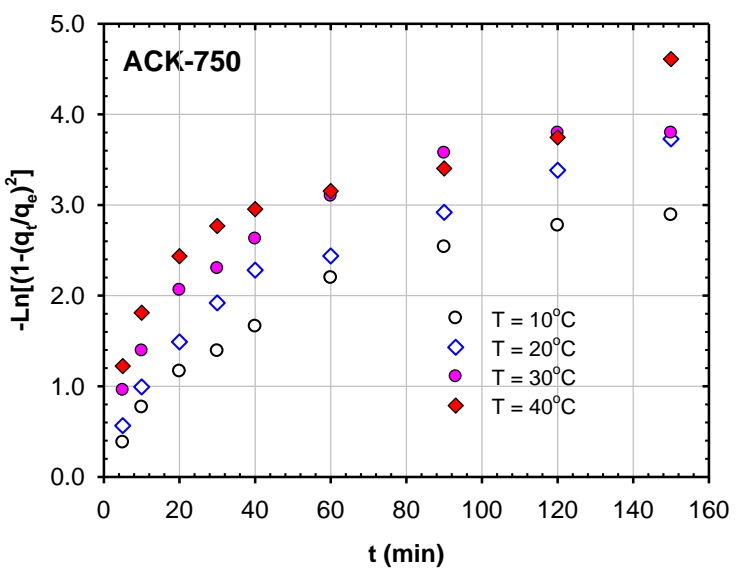

result confirmed that the particle diffusion is not the only rate-controlling step.

Vermeulen plots of $-\ln \left[1-\left(\mathrm{q}_{\mathrm{t}} / \mathrm{q}_{\mathrm{e}}\right)^{2}\right]$ versus $\mathrm{t}$, at different temperatures, are shown in Fig. 7. 
Weber and Morris plots of $\mathrm{q}_{\mathrm{t}}$ versus $\mathrm{t}^{1 / 2}$ are shown in Fig. 8 for ACK-650 and ACK-750 samples at different initial phenol concentrations, and temperatures. For all conditions investigated, there are two separate linear stages. In the first stage, more than $90 \%$ of phenol was adsorbed by activated carbon within $25 \mathrm{~min}$, while in the second stage, a slow diffusion process is observed. Thus, suggesting that a surface diffusion process first governed the adsorption of phenol over coffee husk AC, followed by pore diffusion ${ }^{18}$. Generally, the fast adsorption in the initial stage is governed by film diffusion, and later on, the adsorbate is diffused into the pores.

The intra-particle diffusion rate constant $\left(\mathrm{k}_{\mathrm{d}}\right)$, the intercept $(\mathrm{C})$, and the correlation coefficient $\left(\mathrm{R}^{2}\right)$ for the two stages were determined and summarized in Table 4. $\mathrm{R}^{2}$ is in the range of 0.9367 to 0.9939 , indicating the intra-particle diffusion occurred. Nevertheless, the intercept $\mathrm{C}$ is larger than 0 , which means the plots do not pass through the origin, inferring that intra-particle diffusion is not the sole rate-controlling step. The values of $\mathrm{C}_{2}$ are in the range of 65.27 to $140.50 \mathrm{mg} \mathrm{g}^{-1}$, significantly higher than that of $\mathrm{C}_{1}$ (9.78 to $85.84 \mathrm{mg} \mathrm{g}^{-1}$ ), which suggests a higher boundary layer effect ${ }^{44}$ in the second stage of adsorption. The values of $\mathrm{k}_{\mathrm{d} 1}$ are much larger than that of $\mathrm{k}_{\mathrm{d} 2}$, which can be explained by the limitation of the vacant sites for diffusion, pore blockage effect, and due to the boundary layer effect. It also can be seen that $k_{d}$ is increased with increasing initial phenol concentration and decreased with increasing temperature.

The pore diffusion coefficient $\left(\mathrm{D}, \mathrm{m}^{2} \mathrm{~s}^{-1}\right)$ was calculated by employing the equation (16), assuming the spherical shape of the adsorbent particles ${ }^{45}$ :

$\mathrm{D}=\frac{0.03 \mathrm{r}_{\mathrm{O}}^{2}}{\mathrm{t}_{1 / 2}}$

where $t_{1 / 2}$ is the time ( $s$ ) for half adsorption of phenol, and $r_{o}$ is the average radius of the adsorbent particle in $\mathrm{m}$.

The value of $r_{o}$ was used as $1 \times 10^{-4} \mathrm{~m}$, since the particle radius is in the range of $0.15-0.3 \mathrm{~mm}$, as detailed in the experimental section. The calculated $\mathrm{D}$ is shown in Table 5.

Table 5. Calculated parameters of the Weber and Morris model and the diffusion coefficient.

\begin{tabular}{|c|c|c|c|c|c|c|c|c|c|}
\hline Sample & $\begin{array}{c}\mathrm{C}_{0} \\
\left(\mathrm{mg} \mathrm{L^{-1 }}\right)\end{array}$ & $\begin{array}{c}\mathbf{T} \\
\left({ }^{\circ} \mathbf{C}\right)\end{array}$ & $\underset{\left(\mathrm{mg} \mathrm{g}^{-1} \min ^{-0.5}\right)}{\mathbf{k}_{\mathrm{d} 1}}$ & $\begin{array}{c}\mathrm{C}_{1} \\
\left(\mathrm{mg} \mathrm{g}^{-1}\right)\end{array}$ & $\mathrm{R}_{1}^{2}$ & $\underset{\left(\mathrm{mg} \mathrm{g}^{-1} \min ^{-0.5}\right)}{\mathbf{k}_{\mathrm{d} 2}}$ & $\begin{array}{c}\mathrm{C}_{2} \\
\left(\mathrm{mg} \mathrm{g}^{-1}\right)\end{array}$ & $\mathrm{R}_{2}^{2}$ & $\begin{array}{l}D \times 10^{12} \\
\left(\mathrm{~m}^{2} \mathrm{~s}^{-1}\right)\end{array}$ \\
\hline \multirow{7}{*}{ ACK-650 } & 100 & 30 & 8.48 & 28.21 & 0.9556 & 0.84 & 65.27 & 0.9683 & 1.35 \\
\hline & 150 & 30 & 12.01 & 38.58 & 0.9617 & 1.20 & 90.05 & 0.9576 & 1.37 \\
\hline & 200 & 30 & 13.69 & 45.50 & 0.9531 & 1.36 & 105.81 & 0.9831 & 1.36 \\
\hline & 250 & 30 & 16.24 & 46.82 & 0.9781 & 1.66 & 117.29 & 0.9939 & 1.26 \\
\hline & 150 & 10 & 17.14 & 9.78 & 0.9759 & 2.34 & 83.00 & 0.9593 & 0.65 \\
\hline & 150 & 20 & 14.86 & 23.47 & 0.9655 & 2.01 & 84.75 & 0.9405 & 0.96 \\
\hline & 150 & 40 & 10.06 & 46.66 & 0.9532 & 0.83 & 91.19 & 0.9483 & 1.80 \\
\hline \multirow{7}{*}{ ACK-750 } & 100 & 30 & 7.09 & 50.79 & 0.9544 & 0.54 & 80.31 & 0.9840 & 2.71 \\
\hline & 150 & 30 & 7.91 & 77.86 & 0.9759 & 0.85 & 110.82 & 0.9625 & 3.46 \\
\hline & 200 & 30 & 13.57 & 66.91 & 0.9632 & 1.25 & 126.42 & 0.9805 & 1.91 \\
\hline & 250 & 30 & 18.38 & 60.62 & 0.9746 & 2.01 & 140.50 & 0.9719 & 1.42 \\
\hline & 150 & 10 & 14.88 & 41.90 & 0.9367 & 1.03 & 113.05 & 0.9821 & 1.25 \\
\hline & 150 & 20 & 12.19 & 56.99 & 0.9496 & 0.99 & 112.03 & 0.9897 & 1.85 \\
\hline & 150 & 40 & 5.83 & 85.84 & 0.9300 & 0.43 & 110.37 & 0.9866 & 4.89 \\
\hline
\end{tabular}

The value of $\mathrm{D}$ is between $0.65 \times 10^{-12}$ and $4.89 \times 10^{-12} \mathrm{~m}^{2} \mathrm{~s}^{-1}$. The effect of initial phenol concentration on the diffusion coefficient is not significant, almost unchanged for ACK-650 sample, increase from $2.71 \times 10^{-12}$ to $3.46 \times 10^{-12} \mathrm{~m}^{2} \mathrm{~s}^{-1}$, then decrease to $1.42 \times 10^{-12} \mathrm{~m}^{2} \mathrm{~s}^{-1}$ when initial phenol concentration increase from 100 to $250 \mathrm{mg} \mathrm{L}^{-1}$. However, D is varied from $0.65 \times 10^{-12}$ to
$1.8 \times 10^{-12} \mathrm{~m}^{2} \mathrm{~s}^{-1}$ and from $1.25 \times 10^{-12}$ to $4.89 \times 10^{-12} \mathrm{~m}^{2} \mathrm{~s}^{-1}$, for ACK-650 and ACK-750 samples, respectively, when $\mathrm{T}$ increases from 10 to $40^{\circ} \mathrm{C}$.

The influence of temperature on the diffusion coefficient can be represented by the Arrhenius equation:

$$
\mathrm{D}=\mathrm{D}_{\mathrm{o}} \exp \left(-\frac{\mathrm{E}_{\mathrm{D}}}{\mathrm{RT}}\right)
$$


where $D_{0}$ is the pre-exponential factor, $E_{D}$ is the activation energy of diffusion, $\mathrm{T}$ is the temperature $(\mathrm{K})$, and $\mathrm{R}$ is the gas constant $\left(8.314 \mathrm{~J} \mathrm{~K}^{-1} \mathrm{~mol}^{-1}\right)$.

The equation (17) can be rearranged as:

$\ln \mathrm{D}=\ln \mathrm{D}_{\mathrm{o}}-\frac{\mathrm{E}_{\mathrm{D}}}{\mathrm{R}} \frac{1}{\mathrm{~T}}$

The values of $E_{D}$ and $D_{0}$ were determined from the slope and intercept of the plot of $\operatorname{lnD}$ versus $1 / \mathrm{T}$ (figure not show). $E_{D}$ and $D_{0}$ values for ACK-650 and ACK-750 are $25.163 \mathrm{~kJ} \mathrm{~mol}^{-1}, 2.91 \times 10^{-8} \mathrm{~m}^{2} \mathrm{~s}^{-1}$ and $34.744 \mathrm{~kJ} \mathrm{~mol}^{-1}, 3.14 \times 10^{-6} \mathrm{~m}^{2} \mathrm{~s}^{-1}$, respectively.

\section{Conclusion}

The kinetic adsorption study of phenol onto coffee husk activated carbon revealed that the adsorption process is fast for the ACK-650 sample and extremely fast for the ACK-750 sample. The adsorption process on both samples follows the pseudo-second-order equation, with the maximum adsorption rate of $0.977 \mathrm{~min}^{-1}$ (ACK-750 sample at $40^{\circ} \mathrm{C}$ and initial phenol concentration of $150 \mathrm{mg} \mathrm{L}^{-1}$ ). The adsorption is governed by film diffusion, followed by pore diffusion and has an associated mechanism. The activation energy $\left(\mathrm{E}_{\mathrm{a}}\right)$ of adsorption are 28.083 and $37.133 \mathrm{~kJ} \mathrm{~mol}^{-1}$ for ACK-650 and ACK-750 samples, respectively. The enthalpies of the transition step are $25.610 \mathrm{~kJ} \mathrm{~mol}^{-1}$ for the ACK-650 sample and $34.660 \mathrm{~kJ} \mathrm{~mol}^{-1}$ for the ACK-750 sample. The kinetic data shows that coffee husk activated carbon is a potential adsorbent for removing phenol from wastewater.

\section{References}

1- Y. Zhou, F. Gao, Y. Zhao, J. Lu, Study on the extraction kinetics of phenolic compounds from petroleum refinery waste lye, J. Saudi Chem. Soc., 2014, 18, 589-592.

2- Z. Li, Y. Zhang, L. Wang, Y. Yao, J. Wu, Y. Sun, M. Tian, J. Liu, Phenolic resin modified by boron-silicon with high char yield, Polym. Test., 2019, 73, 208-213.

3- A. Brink, C.M. Sheridan, K.G. Harding, A kinetic study of a mesophilic aerobic moving bed biofilm reactor (MBBR) treating paper and pulp mill effluents: The impact of phenols on biodegradation rates, J. Water Process. Eng., 2017, 19, 35-41.

4- S. Han, J. Cui, L. Gan, X. Zhou, Effects of reaction conditions on the phenol liquefaction of peanut shells, Bioresources, 2019, 14, 1899-1914.

5- C.O. Guimaraes, A.B. Franca, G.R.L. Samanamud, E.P. Baston, R.C.Z. Lofrano, C.C.A. Loures, L.L.R. Naves, F.L. Naves, Optimization of treating phenol from wastewater through the $\mathrm{TiO}_{2}$-catalyzed advanced oxidation process and response surface methodology, Environ. Monit. Assess., 2019, 191, 349.
6- N. Mojoudi, N. Mirghaffari, M. Soleimani, H. Shariatmadari, C. Belver, J. Bedia, Phenol adsorption on high microporous activated carbons prepared from oily sludge: equilibrium, kinetic and thermodynamic studies, Sci. Rep., 2019, 9, 1-12.

7- S.S. Salih, A. Mahdi, M. Kadhom, T.K. Ghosh, Competitive adsorption of As(III) and As(V) onto chitosan/diatomaceous earth adsorbent, J. Environ. Chem. Eng., 2019, 7(5), 103407.

8- S.S. Salih, H.N Mohammed, G.H. Abdullah, M. Kadhom, T.K. Ghosh, Simultaneous removal of $\mathrm{Cu}(\mathrm{II}), \mathrm{Cd}(\mathrm{II})$, and industrial dye onto a composite chitosan biosorbent, J. Polym. Environ., 2020, 28, 354-365.

9- F.F. Barbier, T.G. Chabikwa, M.U. Ahsan, S.E. Cook, R. Powell, M. Tanurdzic, C.A. Beveridge, A phenol/chloroform-free method to extract nucleic acids from recalcitrant, woody tropical species for gene expression and sequencing, Plant Methods, 2019, 15, 62.

10-D. Villanueva-Bermejo, F. Zahran, D. Troconis, M. Villalva, G. Reglero, T. Fornari, Selective precipitation of phenolic compounds from Achillea millefolium L. extracts by supercritical anti-solvent technique, J. Supercrit. Fluid., 2017, 120, 52-58.

11-N. Benosmane, B. Boutemeur, S.M. Hamdi, M. Hamdi, Removal of phenol from aqueous solution using polymer inclusion membrane based on a mixture of CTA and CA, Appl. Water Sci., 2018, 8, 17.

12-T. Wang, Z.Y. Xu, L.G. Wu, B.R. Li, M.X. Chen, S.Y. Xue, Y.C. Zhu, J. Cai, Enhanced photocatalytic activity for degrading phenol in seawater by $\mathrm{TiO}_{2}$-based catalysts under weak light irradiation, RSC. Adv., 2017, 7 , 31921-31929.

13-M.C. Le, K. Le Van, N.H. Nguyen, Theoretical study on the adsorption of phenol on activated carbon using density functional theory, J. Mol. Model., 2013, 19, 4395-4402.

14-N. Mojoudi, N. Mirghaffari, M. Soleimani, H. Shariatmadari, C. Belver, J. Bedia, Phenol adsorption on high microporous activated carbons prepared from oily sludge: equilibrium, kinetic and thermodynamic studies, Sci. Rep., 2019, 9, 19352.

15-K.S. Ukanwa, K. Patchigolla, R. Sakrabani, E. Anthony, S. Mandavgane, A Review of Chemicals to Produce Activated Carbon from Agricultural Waste Biomass, Sustainability, 2019, 11, 6204.

16-L.G.C. Villegas, N. Mashhadi, M. Chen, D. Mukherjee, K.E. Taylor, N. Biswas, A Short Review of Techniques for Phenol Removal from Wastewater, Curr. Pollut. Rep., 2016, 2, 157-167.

17-S. Karthikeyan, B. Sivakumar, N. Sivakumar, Film and Pore Diffusion Modeling for Adsorption of Reactive Red 2 from Aqueous Solution on to Activated Carbon Prepared from 
Bio-Diesel Industrial Waste, J. Chem., 2010, 7, 138684

18-E. Yakub, S.E. Agarry, F. Omoruwou, C.N. Owabor, Comparative study of the batch adsorption kinetics and mass transfer in phenolsand and phenol-clay adsorption systems, Particul. Sci. Technol., 2019, 1-11.

19- Y. Hu, Y. Zhang, Y. Hu, C.Y. Chu, J. Lin, S. Gao, D. Lin, J. Lu, P. Xiang, T.H. Ko, Application of wasted oolong tea as a biosorbent for the adsorption of methylene blue, J. Chem., 2019. Article ID 4980965, 10 pages.

20-E. Lorenc-Grabowska, P. Rutkowski, High adsorption capacity carbons from biomass and synthetic polymers for the removal of organic compounds from water, Water, Air, \& Soil Pollution, 2014, 225, 2082.

21-K. Le Van, T.T. Luong Thi, Activated carbon derived from rice husk by $\mathrm{NaOH}$ activation and its application in a supercapacitor, Prog. Nat. SciMater., 2014, 24, 191-198.

22-P.A. Webb, C. Orr, Analytical methods in fine particle technology, Norcross, Ga.: Micromeritics Instrument Corp, 1997.

23-H.P. Boehm, Surface Oxides on Carbon and Their Analysis: A Critical Assessment, Carbon, 2012, 40, 145-149.

24-American Public Health Association (APHA), Standard Methods for the Examination of Water and Wastewater, $19^{\text {th }}$ ed., Washington DC, 1995.

25-B.H. Hameed, D.K. Mahmoud, A.L. Ahmad, Sorption equilibrium and kinetics of basic dye from aqueous solution using banana stalk waste, J. Hazard Mater., 2008, 158, 499-506.

26-S. Lagergren, Zur theorie der sogenannten adsorption geloster stoffe. Kungliga Svenska Vetenskapsakademiens, Handlingar, 1898, 24, 1-39.

27-V. Vadivelan, K. V. Kumar, Equilibrium, kinetics, mechanism, and process design for the sorption of methylene blue onto rice husk, J. Colloid Interface Sci., 2005, 286, 90-100.

28-W. Yassine, S. Zyade, S. Akazdam, A. Essadki, B. Gourich, D.B. Left, A study of olive mill wastewater removal by a biosorbent prepared by olive stones, Med. J. Chem., 2019, 8, 420-434.

29- A. Srivastava, M. Singh, K. Karsauliya, D.P. Mondal, P. Khare, S. Singh, S.P. Singh, Effective elimination of endocrine disrupting bisphenol $\mathrm{A}$ and $\mathrm{S}$ from drinking water using phenolic resin-based activated carbon fiber: Adsorption, thermodynamic and kinetic studies, Environ. Nanotechnol. Monit. Manage., 2020, 14, 100316.

30-M. de la Luz-Asunción, V. Sánchez-Mendieta, A. L. Martínez-Hernández, V. M. Castaño, C. Velasco-Santos, Adsorption of Phenol from Aqueous Solutions by Carbon Nanomaterials of One and Two Dimensions: Kinetic and Equilibrium Studies, J. Nanomater. 2015, Article ID 405036, 14 pages.

31-M. Gouamid, M.R. Ouahrani, M.B. Bensaci, Adsorption Equilibrium, kinetics, and thermodynamics of methylene blue from aqueous solutions using Date Palm Leaves, Energy Procedia, 2013, 36, 898-907.

32-R.L. Tseng, K.T. Wu, F.C. Wu, R.S. Juang, Kinetic studies on the adsorption of phenol, 4-chlorophenol, and 2,4-dichlorophenol from water using activated carbons, J. Environ. Manage., 2010, 91, 2208-2214.

33-K.P. Singh, A. Malik, S. Sinha, P. Ojha, Liquidphase adsorption of phenols using activated carbons derived from agricultural waste material, J. Hazard. Mater., 2008, 150, 626-641.

34-R.S. Juang, F.C. Wu, R.L. Tseng, Mechanism of Adsorption of Dyes and Phenols from Water Using Activated Carbons Prepared from Plum Kernels, J. Colloid. Interface Sci., 2000, 227, 347-444.

35-M.S. Dabhade, M.B. Saidutta, D.V.R. Murthy, Adsorption of Phenol on Granular Activated Carbon from Nutrient Medium: Equilibrium and kinetic study, Int. J. Environ. Res., 2009, 3, 557-568.

36-F.X. Chen, C.R. Zhou, G.P. Li, F.F. Peng, Thermodynamics and kinetics of glyphosate adsorption on resin D301, Arab. J. Chem., 2016, 9, S1665-S1669.

37-Y. Liu, J. Chen, M. Chen, B. Zhang, D. Wu, Q. Cheng, Adsorption characteristics and mechanism of sewage 2 sludge-derived adsorbent for removing sulfonated methyl 3 phenol resin in wastewater, RSC Adv., 2015, 93, 76160-76169.

38-T.S. Anirudhan, P.G. Radhakrishnan, Thermodynamics and kinetics of adsorption of $\mathrm{Cu}(\mathrm{II})$ from aqueous solutions onto a new cation exchanger derived from tamarind fruit shell, J. Chem. Thermodyn., 2008, 40, 702-709.

39-M. Chairat, S. Rattanaphani, J.B. Bremner, V. Rattanaphani, Adsorption kinetic study of lac dyeing on cotton, Dyes Pigm., 2008, 76, 435-439.

40-D. Mohan, K.P. Singh, Single- and multicomponent adsorption of cadmium and zinc using activated carbon derived from bagasse-An agricultural waste, Water Res., 2002, 36, 2304-2318.

41-D. Reichenberg, Properties of ion-exchange resins in relation to their structure. III. Kinetics of exchange, J. Am. Chem. Soc., 1953, 75, 589-597.

42-G.E. Boyd, A.W. Adamson, L.S. Myers, The exchange adsorption of ions from aqueous solutions by organic zeolites. II. Kinetic, J. Am. Chem. Soc., 1947, 69, 2836-2848.

43-W.J. Weber, J.C. Morriss, Kinetics of adsorption on carbon from solution, J. Sanit. Eng. Div., 1963, 89, 31-60.

44-A.U. Itodo, F.W. Abdulrahman, L.G. Hassan, S.A. Maigandi, H.U. Itodo, Intraparticle diffusion and intraparticulate diffusivities of herbicide on derived activated carbon, Researcher, 2010, 2, 74-86.

45-M. Ahmaruzzaman, D.K. Sharma, Adsorption of phenols from wastewater, J. Colloid Interface Sci., 2005, 287, 14-24. 